\title{
Application of a hydrological-hydraulic modelling cascade in lowlands for investigating water and sediment fluxes in catchment, channel and reach
}

\author{
Jens Kiesel $^{1^{*}}$, Britta Schmalz ${ }^{1}$, Gary L. Brown ${ }^{2}$, Nicola Fohrer ${ }^{1}$ \\ ${ }^{1}$ Department of Hydrology and Water Resources Management, Institute for Natural Resource Conservation, Christian-Albrechts- \\ Universität Kiel, Olshausenstr. 75, 24118 Kiel, Germany. \\ ${ }^{2}$ United States Army Corps of Engineers, Coastal and Hydraulics Laboratory, Engineering Research and Development Centre, (USACE- \\ CHL ERDC), Halls Ferry Road 3909, Vicksburg, MS 39108, USA. \\ ${ }^{*}$ Corresponding author: Tel.: +49(0)431-880-1237. Fax: +49(0)431-880-4607. \\ E-mail: jkiesel@hydrology.uni-kiel.de
}

\begin{abstract}
This study shows a comprehensive simulation of water and sediment fluxes from the catchment to the reach scale. We describe the application of a modelling cascade in a well researched study catchment through connecting stateof-the-art public domain models in ArcGIS. Three models are used consecutively: (1) the hydrological model SWAT to evaluate water balances, sediment input from fields and tile drains as a function of catchment characteristics; (2) the onedimensional hydraulic model HEC-RAS to depict channel erosion and sedimentation along a $9 \mathrm{~km}$ channel onedimensionally; and (3) the two-dimensional hydraulic model AdH for simulating detailed substrate changes in a $230 \mathrm{~m}$ long reach section over the course of one year. Model performance for the water fluxes is very good, sediment fluxes and substrate changes are simulated with good agreement to observed data. Improvement of tile drain sediment load, simulation of different substrate deposition events and carrying out data sensitivity tests are suggested as future work. Main advantages that can be deduced from this study are separate representation of field, drain and bank erosion processes; shown adaptability to lowland catchments and transferability to other catchments; usability of the model's output for habitat assessments.
\end{abstract}

Keywords: SWAT; HEC-RAS; AdH; SEDLIB; Hydrology; Sediment transport; Multiple scales.

\section{INTRODUCTION}

The simulation of river- and aquatic habitat changes, based on environmental and anthropogenic forcing, is an ongoing topic in river research (Jähnig et al., 2012; Kiesel at al., 2009a). The movement and characteristics of water and sediment are pivotal for the functioning of riverine ecosystems (Baron et al., 2002). Water and sediment fluxes are interlinked from the catchment fields down to the instream micro-scale: Water erosion on agriculturally used fields directly affects soil fertility (Uri, 2000). Depending on the geomorphology, high proportions of these eroded, mostly nutrient-rich, fine sediments can enter the streams. In lowland areas and artificially drained wetlands, an additional pathway is the tile drains that contribute sediment to the streams (Kiesel at al., 2009b; Russell et al., 2001). Sediment gets stored, re-entrained, transported or deposited in the streams and becomes part of the instream processes. These processes along the rivers flow paths have various effects on stream properties and habitats (Veihe et al., 2011). They change conveyance, can cause siltation, and can damage waterways, hydraulic structures and adjacent land property. But instream erosion and sedimentation processes are also desired and important characteristics of functioning aquatic ecosystems (Florsheim et al., 2008). On the one hand, this interconnectedness between landscape- and instream processes requires a combined depiction when investigating sediment movement across scales (Deasy et al., 2011; Jarritt and Lawrence, 2007). On the other hand, a quantitative distinction between field and instream erosion is important, for example, for developing target-oriented best management practices for sediment management or when aiming for natural environmental conditions where nutrient loaded fine sediment inputs are less desired than sediment input from banks. In any case, when investigating water induced movement of sediment, it is important that the characteristics of the main driver, the water fluxes, are known (Merritt et al., 2003).

Mathematical modelling of the main processes governing water and sediment transport in a complex environment is a useful and well accepted approach to investigate the impacts on different scales. Hydrologic and hydraulic models can be used in conjunction to depict landscape and instream processes in an interconnected, yet distinct manner to obtain quantitatively discrete results. Numerous studies are available that focus on parts of the integrated hydrological and hydraulic chain, e.g. on catchment hydrology and field erosion (Borah and Bera, 2004), instream hydraulic, sediment transport and delivery processes (Etemad-Shahidi et al., 2010), and micro-scale substrate assessments (Hauer et al., 2010; Pasternack, 2011). However, an integrated and continuous examination of water and sediment fluxes from the catchment down to the micro-reach scale could not be found in the literature. This paper shows such an integrated assessment through the application of a three-step modelling cascade. In order to achieve seamless results, three models need to be run for obtaining model output on all scales, which is in our view the simplest approach. Still, it requires an extensive database and modelling efforts, but the benefits are three-fold: First, temporal and spatial process knowledge on water and sediment fluxes are obtained, second, results are generated seamlessly from the catchment down to the river reach scale and third, through the extensive data input, the model system is potentially able to depict the influence of global change, modifications of catchment properties and channel alterations on different scales up to instream substrates. To fulfil this aim, intermediate objectives have to be defined: (1) the realistic depiction of water fluxes which act as the driving forces in particle transport and (2) the ability to simulate the three main sediment entry pathways in lowlands: field erosion, tile drain sediment input and channel erosion. 


\section{MATERIAL AND METHODS}

Study area

The model cascade is applied in the Kielstau, a northern German lowland catchment, about $10 \mathrm{~km}$ south-east from the city of Flensburg. The low relief of the catchment, its rolling hills topography, high number of landscape depressions and a poorly developed overland drainage system cause low surface runoff fraction, low hydraulic gradients and a significant groundwater influence on the catchment hydrology (Kiesel et al., 2010). Most parts of the catchment are agriculturally used, which is the main reason why $31 \%$ of the catchment area is artificially drained through tile drains, constructed during the second half of the last century. Lake Winderatt, with a surface area of 2 ha, is located in the upper third of the Kielstau River. The lake's water outflow is artificially ponded through a fixed weir. A summary of catchment characteristics is supplied in
Table 1. In the mid-twentieth century, the river channel was straightened and incised, which decreased flow length and stream roughness. Channel slope and flow velocities increased as a result, altering not only the hydraulic regime but also sediment processes. The Kielstau is classified as a lowland gravel bed river, but there are also sections of the stream that are covered with sand layers which show high dynamics over the course of one year. A Water Framework Directive (WFD) monitoring station is located within the Kielstau just upstream of the catchment outlet at gauge Soltfeld. The catchment was chosen to be Germany's UNESCO ecohydrology demo site in 2010 (Fohrer and Schmalz, 2012), also due to the available database collected and research done during the last decade (Schmalz and Fohrer, 2010). The combination of being a well researched study area and the public attention to the catchment's status makes the Kielstau an ideal example for testing new modelling methodologies.

Table 1. Catchment characteristics.

\begin{tabular}{|c|c|c|c|}
\hline Elevation & $\begin{array}{l}28-78 \text { m a.s.1. } \\
\text { (LVA, 1992-2004) }\end{array}$ & Soils & $\begin{array}{l}\text { Haplic and Stagnic Luvisols, Sapric Histosols } \\
\text { (BGR, 1999) }\end{array}$ \\
\hline Size & $\begin{array}{l}50 \mathrm{~km}^{2} \\
(\mathrm{LVA}, 1992-2004)\end{array}$ & Land use & $\begin{array}{l}\text { arable land }(56 \%) \text {, pasture }(26 \%) \text {, forest }(8 \%) \text {, urban }(3 \%) \\
(\text { DLR, 1995; MOBIO, 1999) }\end{array}$ \\
\hline Population & $\begin{array}{l}4450 \\
\text { (Golon, 2009) }\end{array}$ & Tile drains & $\begin{array}{l}31 \% \text { of catchment area } \\
\text { (Fohrer et al., 2007) }\end{array}$ \\
\hline $\begin{array}{l}\text { Longest flow } \\
\text { path }\end{array}$ & $\begin{array}{l}16.2 \mathrm{~km} \\
(\mathrm{LVA}, 1992-2004)\end{array}$ & Climate & $\begin{array}{l}\text { mean: } 8.2^{\circ} \mathrm{C}, 893 \mathrm{~mm} \text { precipitation } \\
(\mathrm{DWD}, 2010)\end{array}$ \\
\hline Mean slope & $\begin{array}{l}1.2 \% \\
\text { (LVA, 1992-2004) }\end{array}$ & Runoff & $\begin{array}{l}\text { mean: } 0.42 \mathrm{~m}^{3} \mathrm{~s}^{-1} \text { at gauge Soltfeld } \\
(\mathrm{LKN}, 2010)\end{array}$ \\
\hline
\end{tabular}

\section{Description of the model cascade}

We propose the consecutive application of three models: a hydrologic model, a one-dimensional hydraulic model and a two-dimensional hydraulic model. Fig. 1 shows the application range of each individual model within the three-step model cascade. The maps on the left hand side visualise the scale on which each model is applied. The flowchart on the right hand side describes the impacts (white on black) that are depicted with each model and the results (black on grey) which are used as an input to the next model on the lower scale. The flowchart illustrates that this consecutive application leads to a consideration of large scale impacts on small scales. It is important to note that this consideration can only be successful if a continuous temporal and spatial connection between the models is established and if the same time period is simulated in the three models. For each model, the application scale is summarized in Table 2, as well as the time for which the models are run and the parameters which are transferred to the next model.

First, the Soil and Water Assessment Tool (Arnold et al., 1998; SWAT, version 2005) is applied on the whole catchment area of the Kielstau (Fig. 1a). The model can be used for simulating the impact of catchment characteristics, climate and land use management on catchment water balance and sediment. The SWAT model and its source code are freely available. It has been and is applied in various EU Water Framework Directive related projects (Arnold and Fohrer, 2005) and by the US Environmental Protection Agency, the US Department of Agriculture as well as by universities and consultants around the world (Gassman et al., 2007). The application ranges from the field scale (Maharjan et al., 2013) to simulations of continents (Schuol et al., 2008) in hourly to yearly time steps. Within the model cascade, SWAT is used to simulate runoff contribution and sediment input from the catchment to the reach. Although SWAT's channel erodibility processes have shown to give comparable degradation results to a HEC-RAS model (Allen et al., 2008), SWAT's spatial representation through subbasins is disadvantageous for obtaining differentiated instream results along a stream channel since the same result value is given for each reach, which can be many kilometres long.

Table 2. Information about model application within the model cascade.

\begin{tabular}{llll}
\hline Model & Scale & Time & Parameters transferred from model output to next model \\
\hline \multirow{2}{*}{ SWAT } & Catchment: & $(1999-2009)$ & flow from groundwater and fields \\
& $50 \mathrm{~km}^{2}$ & $04 / 2008-04 / 2009$ & sediment load from fields, drains with additional model SEPAL \\
\multirow{2}{*}{ HEC-RAS } & Reach: & $(2007-2009)$ & stream discharge \\
& $9 \mathrm{~km}$ & $04 / 2008-04 / 2009$ & total sediment load \\
\multirow{2}{*}{ AdH } & Reach: & $(04 / 2008-04 / 2009)$ & \\
& $230 \mathrm{~m}$ & $04 / 2008-04 / 2009$ & - \\
\hline
\end{tabular}



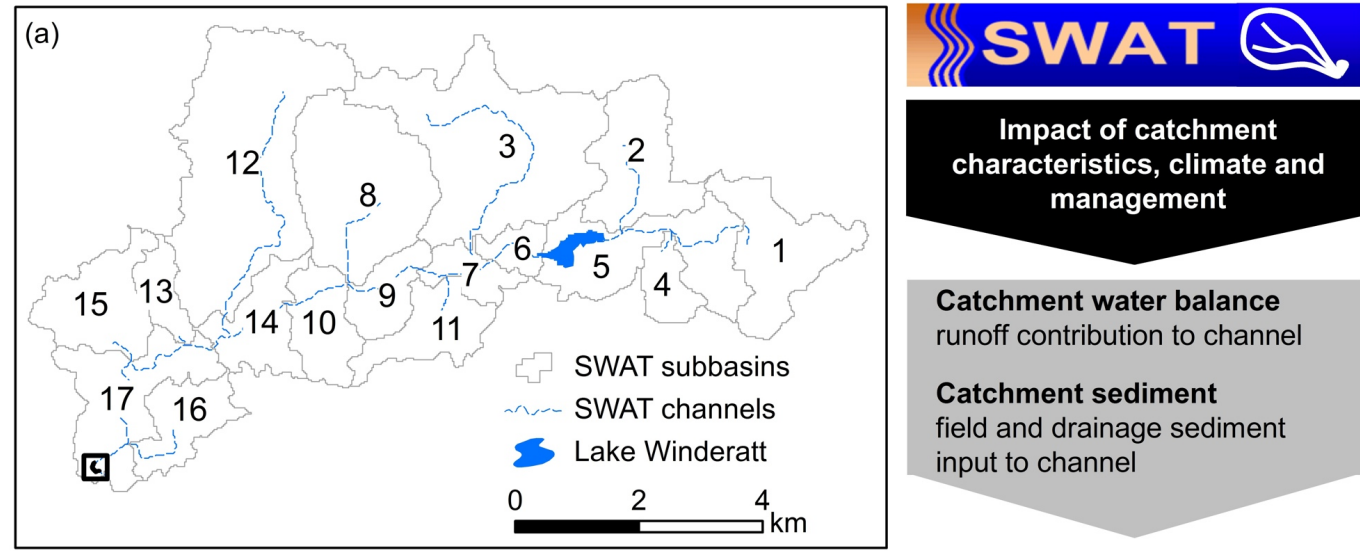

Impact of catchment

characteristics, climate and management

Catchment water balance runoff contribution to channel

Catchment sediment field and drainage sediment input to channel


\section{Small scale 2D-hydraulics velocities and water depths in high resolution}

\section{Substrate changes erosion and deposition in high resolution}

Fig. 1. SWAT, HEC-RAS and AdH application in a modelling cascade. SWAT model domain (a) with Lake Winderatt in subbasin 5 and location of the outlet at gauge Soltfeld marked with rectangle, HEC-RAS model domain (b) with location of measurement locations (A, B, $\mathrm{C})$, AdH model domain upstream of gauge Soltfeld including location of measured cross sections $\mathrm{a}-\mathrm{h}(\mathrm{c})$ and a detailed part of the triangular element mesh with material boundaries (d).

The decision to use a separate instream model for depicting processes in the main channel is thus driven by the need for high resolution results with output parameters that the SWAT model is not able to supply, e.g. velocity distributions along the rivers flow path. The one-dimensional hydraulic model Hydrologic Engineering Centres River Analysis System (HEC-RAS, US Army Corps of Engineers, 2010) is used to simulate the $9 \mathrm{~km}$ main channel downstream of Lake Winderatt to gauge Soltfeld at the catchment outlet (Fig. 1b). HEC-RAS is a well tested and widely applied model which has been developed by the USACE-Hydrologic Engineering Centre and is also available in the public domain. The model is utilised by major US water related administrations, universities and engineers worldwide. The application ranges from small scale drainage systems to large river networks, comprising sub-hourly peak flow calculations as well as simulations for years (SWWRP, 2011). Within the model cascade, the HEC-RAS model is used to simulate hydraulic stream parameters as well as erosion and sedimentation within the channel.

As it is not possible to satisfactorily depict detailed processes on broad and short river sections or to assess seamless spatial coverage, small scale hydraulic impact on substrates with the HEC-RAS model, the model Adaptive Hydraulics (AdH, Berger et al., 2011) linked to the SEDLIB sediment transport library (Brown et al., 2012) is used to simulate the $230 \mathrm{~m}$ long river section upstream of gauge Soltfeld. AdH is developed at the Engineering Research and Development Centre (ERDC) from the USACE. It is capable of simulating the impact of stream properties, upstream hydraulics and sediment transport on small scale hydraulics and substrates. AdH can describe both 
saturated and unsaturated groundwater, overland flow, 3D Navier-Stokes and 3D shallow water problems, in addition to the 2D shallow water module applied here (Berger et al., 2011). The software is also available in the public domain. AdH runs on both Windows and UNIX based multi- processor machines and is fully parallelised. In the near future, the model will be dynamically linked to HEC-RAS (Brunner, 2011). The user can set thresholds which define the accuracy of the calculated result. The model meets these thresholds by an automatic adaption of mesh resolution and time steps during model runs. Within the model cascade, AdH is used to simulate velocities and water depths as well as erosion and deposition of sediments in high resolution and two-dimensionally.

\section{Data transfer within the model cascade}

SWAT daily flow and sediment load output time series for every subbasin are necessary boundary condition input data to HEC-RAS. A SWAT-HEC-RAS interface was developed (Kiesel et al., 2012) that overlays the SWAT catchment map with the HEC-RAS model domain. It assembles quasi unsteady flow values, which are steady flow values over defined time increments, for every HEC-RAS cross section. The SWAT model's sediment load values for every time step are allocated to the tributaries draining into the channel modelled with the HECRAS model.

Data transfer from the HEC-RAS model to the AdH model can be achieved without the usage of additional tools. Flow and sediment load time series from the HEC-RAS cross section upstream of the AdH model boundary can be directly copied to the AdH input file.

\section{Model algorithms for water processes}

SWAT depicts the land phase of the hydrological cycle and its impacts by natural and anthropogenic processes on any hydrologically relevant area. For the present study, the PenmanMonteith equation for evapotranspiration, the SCS curve number method for modelling surface runoff, and the kinematic storage model for interflow are used. The SWAT model calculates the water balance of two groundwater aquifers. The first aquifer enables return flow to surface water or can be tapped through plants, while groundwater entering the second aquifer is lost from the system. A variable storage coefficient method is used to route the flow components across user defined subbasins to the catchment outlet. Spatially explicit streamflow values are available at each subbasin outlets which can be used to depict tributary flows to main channels (Neitsch et al., 2009).

The HEC-RAS model is used to simulate one-dimensional open channel hydraulics in river networks at user defined cross sections. Within this study, steady state simulations are used for each individual SWAT daily time step. Hydraulic parameters are calculated through the energy equation which is solved with the standard step method in case of basic flow problems. For mixed flow regimes and for hydraulic structures the momentum equation is applied within HEC-RAS. For each simulated cross section location, depth- and width averaged parameter values are calculated for the channel (USACE, 2010).

For the present study, AdH is used to simulate twodimensional shallow water flow in a natural, open channel. Therefore, the depth-averaged Navier-Stokes equation is solved for the triangular finite element mesh. The numerical solvers available in AdH are UMFPACK (Davis, 2004) or ParMETIS (Karypis and Kumar, 1998), of which the first was applied in this study.

\section{Model algorithms for sediment processes}

SWAT employs the Modified Universal Soil Loss Equation (MUSLE, Williams, 1995) to calculate field erosion. Through the exchange of the original rainfall erositivity factor of the USLE against a runoff factor, the MUSLE is assessed more applicable to single events and to consider delivery ratios (Williams, 1995). Erosion types that can be depicted with the MUSLE are sheet and rill erosion, which we refer to as field erosion. Besides field erosion, tile drains are another source of sediment from lowland catchments to the water bodies (Chapman et al., 2005; Kiesel at al., 2009b). The SWAT model is currently not able to depict sediment input from tile drains to the stream. Other modelling concepts to depict this pathway are not available either. A methodology was developed to model daily tile drain sediment loads. The impact of tile drains on the catchments sediment load has been assessed with a GIS-based tool together with field measurements (SEPAL, Kiesel et al., 2009b). In this study of the Kielstau catchment, the long-term, basin-wide average tile drain sediment input fraction was found to be $15 \%$ and field sediment input was $14 \%$ which is in coherence with studies carried out in catchments with similar characteristics (Kronvang et al., 1997). Based on these fractions, the yearly tile drain sediment load is calculated for each subbasin individually:

$S T_{y i}=S F_{y i} \cdot \frac{f r_{T}}{f r_{F}}$,

where $i$ is the subbasin, $S T_{y}$ is the sediment load from tile drains for the current year $(\mathrm{kg}), S F_{y}$ is the yearly sediment load from field erosion calculated by SWAT $(\mathrm{kg}), f r_{T}$ is the tile drain (\%) and $f r_{F}$ is the field sediment input fraction (\%) supplied by SEPAL. Together with SWAT's daily modelled tile drain flow, $S T_{y}$ is used to calculate daily sediment load from fields and drains for each subbasin:

$$
S_{\text {TOTdi }}=S F_{d i}+\frac{Q T_{d i}}{Q T_{y i}} \cdot S T_{y i}
$$

where $S_{\text {TOTd }}$ is the total daily sediment load from fields and tile drains $(\mathrm{kg}), S F_{d}$ is the daily sediment load from field erosion calculated by SWAT $(\mathrm{kg}), Q T_{d}$ is the daily tile drain flow $\left(\mathrm{m}^{3}\right), Q T_{y}$ is the yearly tile drain flow $\left(\mathrm{m}^{3}\right)$. The equations presented here are not implemented in SWAT, but applied on SWATs MUSLE and tile drain flow output to obtain the total daily sediment load to the catchments streams.

For each time increment and each cross section, HEC-RAS solves the sediment continuity equation to compute the change in sediment volume based on the sediment transport capacity of the water. Bed elevation change and grain size distribution are then calculated at each node of all cross sections, which makes a spatially explicit depiction of erosion and sedimentation over time possible (USACE, 2010).

Similarly to the HEC-RAS model, the AdH model requires substrate information, sediment influx and discharge time series. For each time step, an active layer is calculated within the AdH model which acts as a source of sediment to the bed layers 
in case of depositing sediment and as a sink of sediment from the bed layers in case of eroding sediment. Sediment transport capacity is computed for suspended transport and for bed load transport individually. Grain size distributions, bed layer properties and bed elevation changes are available across and along the river bed at every node of the triangular surface mesh.

\section{Setup and calibration for modelling water fluxes}

The data presented in Table 3 are used for driving the models' hydrological and hydraulic algorithms. All necessary data for the simulations are summarized there individually for each model. Data are obtained mainly from official sources, reports and own measurement campaigns (Table 3 ). The type of data is given through the information in brackets. The ArcGIS interface ArcSWAT (Winchell et al., 2007) is used to prepare SWAT model input data from spatial datasets. During the SWAT model setup and calibration process it is of importance to consider the hydrologic impact of tile drainages and landscape depressions of the Kielstau catchment (Kiesel et al., 2010). Therefore, tools are used to obtain a spatially distributed drainage map (DRAINdist, Fohrer et al., 2007) and to estimate the surface water retention potential based on the consideration of closed sinks in a high quality digital elevation model (ERPL, Kiesel et al., 2010). The catchment is divided in 17 subbasins, so that all tributaries to the main channel of the Kielstau River are represented (Fig. 1a). The model is run with a ten year climate dataset from 1999-2009 (calibration 1999-2003, validation 2004-2009) and discharge is calibrated first manually and then automatically on the catchment outlet. Most sensitive are groundwater (return flow threshold), surface water (curve number) and routing parameters (channel conductivity). The detailed SWAT model setup and calibration is described in Kiesel et al. (2010).

HEC-RAS geometry data are derived from LiDAR data (LVA, 2008) of the floodplains and instream cross sectional measurements. Bathymetry is interpolated in between the cross sections with a GIS tool (Merwade et al., 2008). The resulting instream grid is merged to the LiDAR floodplain DEM with spline interpolation. Cross sections for the conveyance calculations are extracted from this surface DEM to HEC-RAS in an average distance of $17 \mathrm{~m}$ spacing depending on the curvature of the stream using the interface HEC-GeoRAS (USACE, 2011). Information about channel characteristics is available from the state-wide river mapping scheme (DAV-WBV/LAND SH, 2006) divided into stream sections of about 10-200 m length depending on stream variability. Manning's $n$ values for the channel are derived from these data using the roughness formula first proposed by Chow (1959). The formula incorporates substrate material, surface irregularities, channel cross section variation, obstructions, vegetation and meandering properties of the channel. Daily flow values are supplied from the SWAT model via the SWAT-HEC-RAS interface. The HEC-RAS model output can be compared at three locations (Fig. 1b) along the main channel against measured water depths and flow velocities for 24 flow events $\left(0.06-1.26 \mathrm{~m}^{3} \mathrm{~s}^{-1}\right.$, Tavares, 2006). Manning's $\mathrm{n}$ values are adapted within plausible ranges to match observed data. The calibrated channel Manning's $n$ values range between $0.02-0.06$ with a medium value of 0.04 .

For setting up the AdH model at the detailed $230 \mathrm{~m}$ long river section, it is not possible to use commonly area-wide available data. Field surveys have been carried out with differential GPS and water depth measurements to record 22 cross sections for interpolating the stream's bathymetry which is merged to the LiDAR-derived floodplain. Due to the small stream width of mainly $4 \mathrm{~m}$, extensive care had to be taken to obtain measurements with a high accuracy, especially close to the stream banks. Additionally, a morphological mapping campaign has been conducted to obtain a shapefile of substrate distributions (Thiemann, 2008). The shapefile and surface DEM are used to create the triangular computation mesh with ArcADH, an ArcGIS interface for AdH (Kiesel et al., 2012). Higher mesh resolution is assigned to regions in bends and highly variable substrates. Element sizes are between 0.08 and $0.2 \mathrm{~m}^{2}$ in the channel and $5 \mathrm{~m}^{2}$ in the floodplains. Manning's $\mathrm{n}$ values are defined for each mapped substrate. Higher roughness values are assigned to boulders, vegetation and dead wood as the thickness of these structures induce additional energy losses. Estimated eddy viscosities and Manning's n values are calibrated to match measured water surface slope and velocities at eight cross sections within the modelling domain (Fig. 1c).

\section{Setup and calibration for modelling sediment fluxes}

On the basis of the calibrated water fluxes model cascade, the erosion and sediment transport algorithms of SWAT, HECRAS and AdH are parameterised and calibrated with data shown in Table 4, which need to be available in addition to the data presented in Table 3. Characteristics and structure of Table 4 is similar to Table 3 . Daily sediment input from fields is simulated with the SWAT model. Daily tile drain sediment input to the stream is depicted with Eqs. (1) and (2). Calibration of the SWAT model is carried out by comparing modelled to measured long-term yearly average sediment loads and by comparing simulated and observed daily sediment load dynamics. Adjusted model parameters are slope lengths, support practice factor and widths of vegetated buffer strips.

The resulting total sediment time series are handed over to the HEC-RAS model using a SWAT-HEC-RAS interface (Kiesel et al., 2012). Sediment grain size distributions of the SWAT time series are calculated from topsoil parameters, which are weighted according to the areal soil type distribution within each subbasin. Substrate grain size distribution of the river bed and banks complete the input data. Subbasins and channels upstream of Lake Winderatt are excluded from the sediment calculations since the lake acts as a sediment sink. The HECRAS model is calibrated to the measured total sediment load by fitting the most suitable sediment transport equation, sorting, armouring and fall velocity methods and by adjusting the density of sediments. Six sediment transport equations are implemented in the HEC-RAS model: Ackers and White, Copeland's form of Laursen, Meyer-Peter-Müller, Toffaleti, Yang, Wilcock (USACE, 2010). The user has to choose the most appropriate one during the calibration process. The Toffaleti formula (Toffaleti, 1968) is the most suitable for calculating the sediment transport potential for the local conditions. This total load function has been developed for conditions with a significant amount of suspended load and sand transport (USACE, 2010) which are both typical for the sediment transport in the Kielstau River (Labadi, 2009). The decision is furthermore supported by Yang and Wan (1991), who found good performance and accuracy of the formula in natural rivers compared to other formulas. Sediment transport calculations are carried out with the Exner 5 sorting routine and Toffaleti fall velocity method.

Sediment and water fluxes time series with a daily time step are transferred to the AdH model at the respective cross section that defines the upstream AdH model domain boundary. Besides the influx time-series, sediment input data necessary for the AdH model is comprised of properties for distinct grain size classes and bed layers. These are taken from a morphological 
Table 3. Data for depicting water fluxes in the Kielstau catchment, data type in brackets.

\begin{tabular}{|c|c|c|}
\hline & Used data & Data source and format \\
\hline \multirow{11}{*}{ 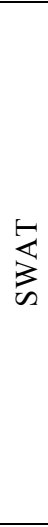 } & Digital Elevation Model & $25 \times 25 \mathrm{~m}$ and $5 \times 5 \mathrm{~m}$ DEM (LVA, 1992-2004; LVA, 2008) $\mid$ (GIS) \\
\hline & Stream network & DAV-WBV/LAND SH (2006) $\mid$ (GIS) \\
\hline & Soil map & BÜK 1 : 200.000 (BGR 1999) | (GIS) \\
\hline & Drain map & Fohrer et al., (2007) |(GIS) \\
\hline & Physical soil parameters & $\begin{array}{l}\text { Borehole profile (LANU, 2006); Ad-Hoc-AG Boden (2005); Baumer } \\
\text { (1990); Janßen (2006); Post et al., (2000); Succow and Joosten (2001) } \\
\text { (GIS, text) }\end{array}$ \\
\hline & Land use map & DLR, 1995; MOBIO, $1999 \mid$ (GIS) \\
\hline & Vegetation parameters & SWAT database (Neitsch et al., 2009) $\mid$ (table) \\
\hline & Crop rotations and management & Bieger (2007) $\mid$ (text) \\
\hline & Lake properties & Grudzinski (2007) | (text) \\
\hline & $\begin{array}{l}\text { Climate data (precipitation, tempera- } \\
\text { ture, humidity, wind, solar) }\end{array}$ & $\begin{array}{l}\text { DWD (2010) station Meierwik; IFM (2007); dew point calculation accord- } \\
\text { ing to Sonntag and Heinze (1982) } \mid \text { (table) }\end{array}$ \\
\hline & Discharge data for calibration & Discharge gauge Soltfeld (LKN, 2010) $\mid$ (table) \\
\hline \multirow{9}{*}{ 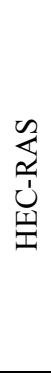 } & Stream network & DAV-WBV/LAND SH (2006) $\mid$ (GIS) \\
\hline & Cross sections & soilAQUA (2009) $\mid$ (table) \\
\hline & $1 \mathrm{~m}$ DEM of floodplains & LVA (2008) $\mid$ (GIS) \\
\hline & $\begin{array}{l}\text { Hydraulic roughness of stream bed and } \\
\text { banks (Manning's n values) }\end{array}$ & $\begin{array}{l}\text { Vegetation and physical properties from DAV-WBV/LAND SH (2006); } \\
\text { calculation according to Chow (1959) } \mid \text { (GIS, text) }\end{array}$ \\
\hline & Hydraulic roughness of floodplains & Field mapping; Chow (1959) | (GIS, text) \\
\hline & Hydraulic structures (bridges) & 1 m DEM (LVA 2008); aerial photos (LVA, 1992-2004) |(GIS) \\
\hline & Discharge hydrographs & from SWAT simulation $\mid$ (table) \\
\hline & Discharge rating curve & LKN (2010) $\mid$ (table) \\
\hline & Water level and flow velocities & Tavares (2006) $\mid$ (table) \\
\hline \multirow{5}{*}{$\underset{\nabla}{\frac{\pi}{2}}$} & Discharge hydrograph & from HEC-RAS simulation | (table) \\
\hline & Substrate distribution & Thiemann (2008); field mapping | (GIS) \\
\hline & Grain size distribution of substrates & Labadi (2009); Thiemann (2008) $\mid$ (table) \\
\hline & $\begin{array}{l}\text { Detailed data for hydraulic roughness } \\
\text { of bed and banks }\end{array}$ & Field mapping; Chow (1959); Thiemann (2008) $\mid$ (GIS, Text) \\
\hline & Detailed topography & Surveying; LVA (2008) | (GIS) \\
\hline
\end{tabular}

Table 4. Additional data to Table 3 for depicting sediment fluxes, data type in brackets.

\begin{tabular}{|c|c|c|}
\hline & Used data & Data source and format \\
\hline \multirow{4}{*}{ 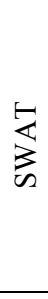 } & $\begin{array}{l}\text { Soil erositivity and coarse fragment } \\
\text { factor, cover and management factor, } \\
\text { support practice factor }\end{array}$ & $\begin{array}{l}\text { LANU (2006); Ad-Hoc-AG Boden (2005); Dickinson et al., (1989); } \\
\text { Neitsch et al., (2009); Schwertmann et al., (1987); Williams et al., (1995) } \\
\text { | (GIS, table, text) }\end{array}$ \\
\hline & $\begin{array}{l}\text { Suspended sediment concentration in } \\
\text { sewage plant discharges }\end{array}$ & Andersen $(2006) \mid($ table $)$ \\
\hline & $\begin{array}{l}\text { Long-term average sediment input ratio } \\
\text { from field- and tile drains }\end{array}$ & Modelling with SEPAL (Kiesel et al., 2009b) | (text) \\
\hline & Suspended sediment concentration & Sampling and analysis $\mid$ (table) \\
\hline \multirow{3}{*}{ 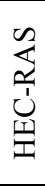 } & $\begin{array}{l}\text { Sediment graphs with grain size distri- } \\
\text { bution }\end{array}$ & from SWAT simulation and physical soil parameters $\mid$ (table) \\
\hline & $\begin{array}{l}\text { Grain size distribution river bank and } \\
\text { bed }\end{array}$ & DAV-WBV/LAND SH (2006) | (table) \\
\hline & Suspended sediment concentration & Sampling and analysis $\mid$ (table) \\
\hline \multirow{4}{*}{$\overline{\bar{z}}$} & $\begin{array}{l}\text { Sediment graphs with grain size distri- } \\
\text { bution }\end{array}$ & from HEC-RAS simulation | (table) \\
\hline & Physical substrate parameters & Ad-Hoc-AG Boden (2005) $\mid$ (text) \\
\hline & Bed load transport & Field measurements; Labadi (2009) $\mid$ (table) \\
\hline & Substrate changes over time & Substrate mapping (Thiemann 2008, field mapping in 2009) $\mid$ (GIS) \\
\hline
\end{tabular}

mapping campaign where besides the movable sediment, wood debris, vegetation and boulders have been recorded (Thiemann, 2008). 18 evenly distributed substrate samples have been taken in the stream section from which grain sizes have been analysed in the laboratory. The target parameter for the calibration is the change of the $\mathrm{d} 90$ for the upper $5 \mathrm{~cm}$ of the river bed between April 2008 and April 2009 for which observed substrate changes are available (Table 4). Similar to the HEC-RAS model, the model $\mathrm{AdH}$ is calibrated by fitting the most suitable sediment transport equations out of three suspended load formulas (Garcia-Parker, Wright-Parker and van Rijn) and out of three bed load formulas (van Rijn, Meyer-Peter-Müller, Meyer-PeterMüller with Wong Parker correction) and by adjusting the density of sediments. The sediment transport equations that yielded the best results for the application in the Kielstau River are Wright-Parker (Wright and Parker, 2004) for the suspended entrainment and Meyer-Peter Mueller with Wong-Parker correction (Wong and Parker, 2006) for the bedload entrainment. 


\section{RESULTS}

\section{Results - water fluxes}

In order to assess model performance on the three scales, simulation results are compared to temporally and spatially distributed measurements. The SWAT model shows good agreement with observed daily discharge at the catchment outlet for the five year calibration and five year validation period $\left(r^{2}=0.82, \mathrm{NSE}=0.78\right.$, Fig. 2$)$. Most problematic is the depiction of peak flows (Fig. 2) which is most likely due to (1) the availability of only one climate station $5 \mathrm{~km}$ outside the watershed and (2) the availability of daily aggregated precipitation data, which is too coarse, since the time of concentration of the Kielstau, calculated using the Kirpich (1940) formula, is about $7 \mathrm{hrs}$. Additional results and final calibrated parameters can be found in Kiesel et al. (2010).

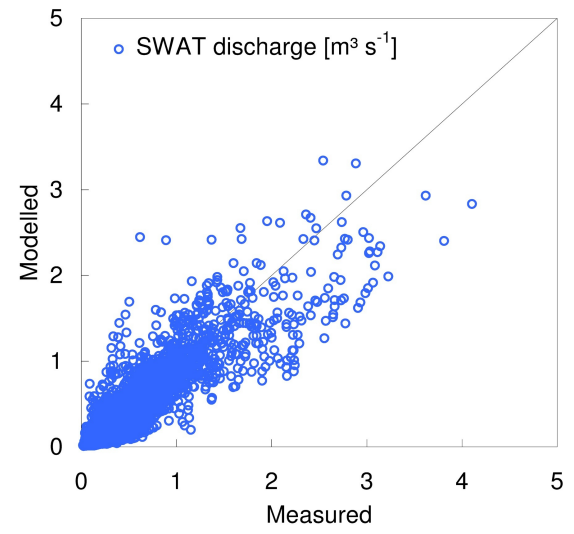

Fig. 2. Comparison of daily calculated and measured discharges for the modelling period 1999-2009.

The HEC-RAS model, driven with flow data from SWAT, generally matches measured water depths $\left(r^{2}=0.90\right.$, Fig. 3a) and flow velocities $\left(r^{2}=0.88\right.$, Fig. $\left.3 b\right)$ at the three locations well. The scatter plots enable a direct comparison between measured and modelled hydraulic parameters for different discharge events. At site B, located in the middle section of the stream, the model underestimates highest measured water depths at three occasions while flow velocities are overestimated. At site A, both velocity and depth are underestimated for the highest depth and flow event, which is probably due to a measurement error.

The two-dimensionality of the AdH simulations makes a spatially distributed comparison in $\mathrm{x}$ - and y-direction necessary, which is especially important for the calibration process. In addition, by comparing simulated with observed hydraulic parameters along and across the stream section, strengths or weaknesses in the sediment transport simulations can be explained. The AdH model results at the eight cross sections match measured water depths very well (Fig. 4). At some locations, the model underestimates water depths which are predominantly close to the river banks (a, c, f, g, h). Flow velocity distributions are simulated sufficiently well but are depicted less accurate than water depth. The locations at the banks show highest deviations and the return flow, as observed at cross sections $\mathrm{d}$ and $\mathrm{g}$, could not be simulated. The three models are fit as thoroughly as possible to measured data, as good model performance in hydrology and hydraulics is paramount for realistically depicting erosion, sediment transport and deposition.
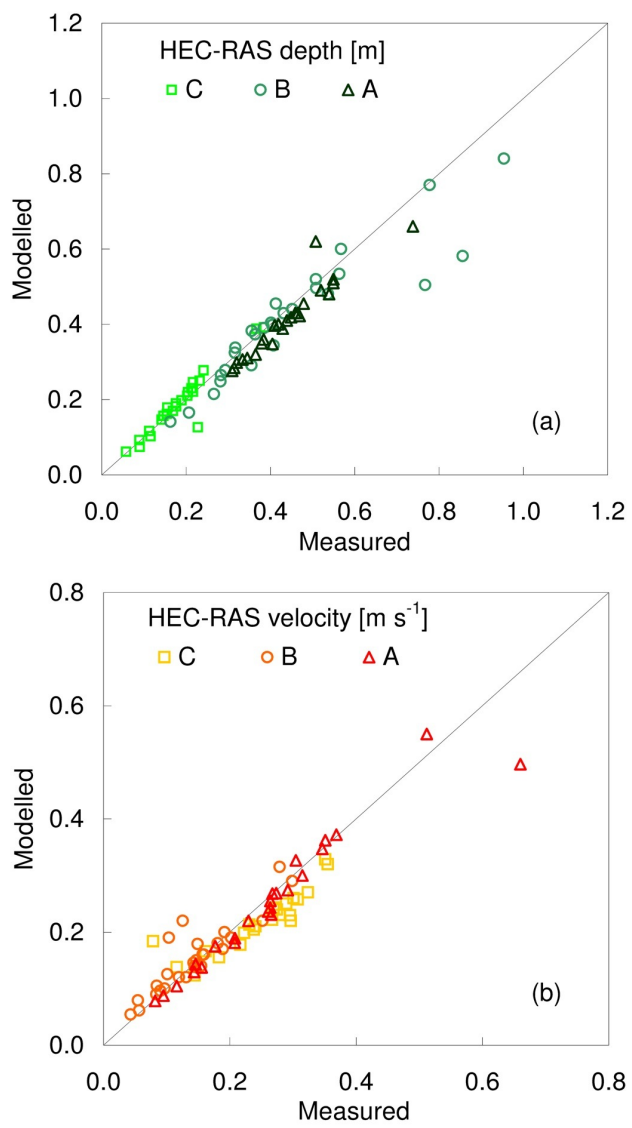

Fig. 3. Comparison of calculated and measured hydraulic parameters at locations A, B, C (see Fig. 1b): (a) flow depth and (b) flow velocity.

\section{Results - sediment fluxes}

Agreement of modelled with observed sediment load leaving the watershed is an important indicator for the plausibility of the SWAT and HEC-RAS models. At the catchment outlet, modelled and measured sediment load is compared. The modelled sediment pathways are distinguished in Fig. 5 where the daily distribution of the field, drain and total sediment load is plotted against measured values $\left(r^{2}=0.56, \mathrm{NSE}=0.26\right)$. Modelled sediment load leaving the fields, drains and the channel bed and banks account for $1.6 \%, 18.0 \%$ and $80.4 \%$ respectively during the target time period of April 2008 to April 2009. The modelled ratios between the three pathways are governed by the flow components surface runoff, tile flow and stream flow and thus represent the hydrologic situation during the April 2008 to April 2009 time period: The ten most extreme storm events in this period are $40 \%$ lower than in other years, a situation which seems to have caused unusually low field erosion. Calculating the sediment transport ratios over three years, from 2007 to 2009 , yields a ratio of $17.1 \%$ from fields, $18.3 \%$ from drains and $64.5 \%$ from the channel, which is comparable to other studies in the same or similar environments (Kiesel et al., 2009b; Kronvang et al., 1997). In comparison to field and drains, the channel banks and bed are more constantly contributing sediment. The model depicts the pattern and magnitude reasonably well, but the single highest measured sediment load during the modelling period (February 2009, $8.4 \mathrm{t} \mathrm{d}^{-1}$ ) could not be reproduced. It is unclear if the discrepancy refers to a measurement error or a physical explanation like a bank collapse. 
A hydrological-hydraulic modelling cascade for investigating water and sediment fluxes in catchment, channel and reach

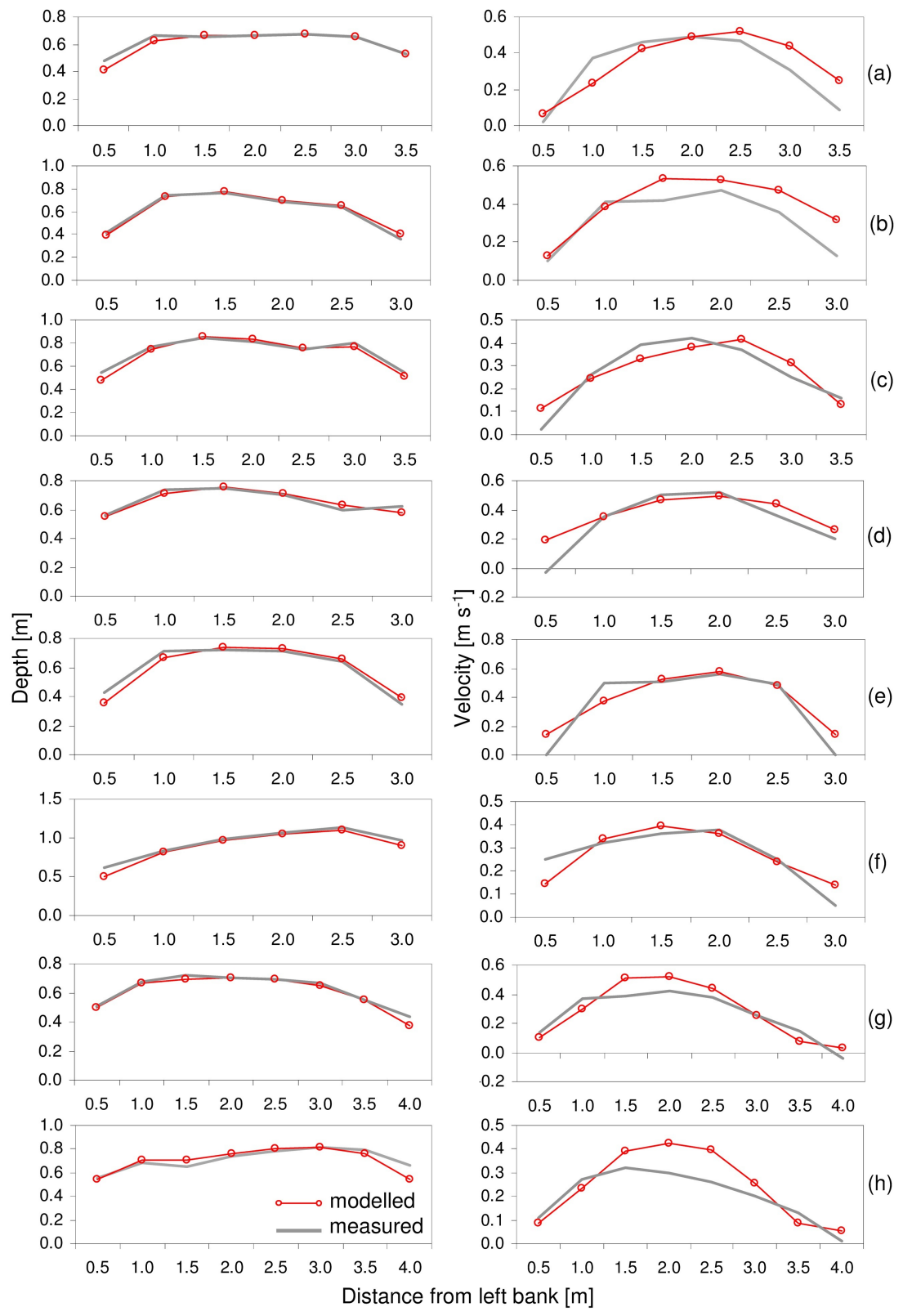

Fig. 4. Comparison of calculated and measured hydraulic parameters at cross sections a-h (see Fig. 1c): (left) flow depth; (right) flow velocity.

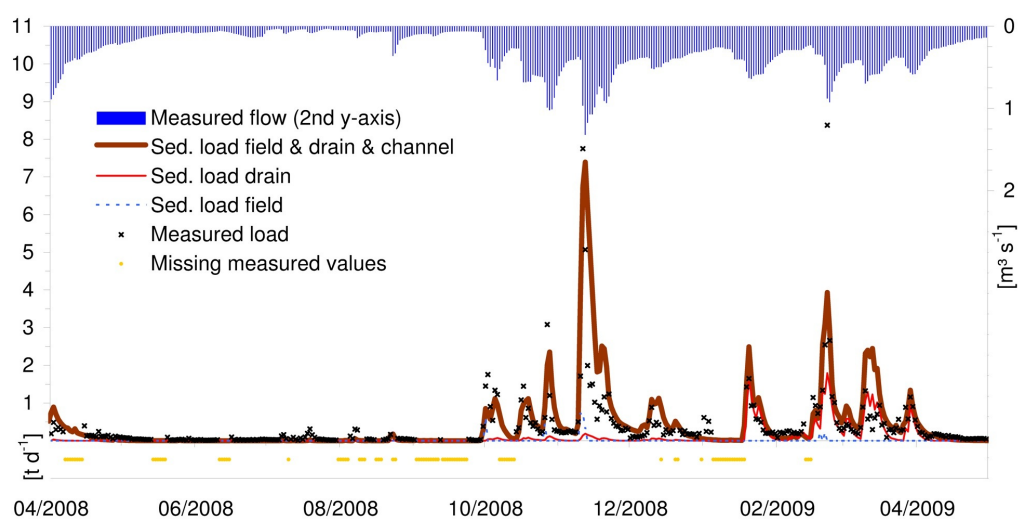

Fig. 5. Modelled sediment load from field simulated with SWAT, tile drain depicted with SEPAL (Kiesel et al., 2009b) and Eqs. (1) and (2), modelled sediment load from field and drain and channel in combination with HEC-RAS; all compared to measured values; note missing measured values below $\mathrm{x}$-axis. 




Fig. 6. d90 of the upper $5 \mathrm{~cm}$ of the river bed, April 2008 source data and comparison of modeled AdH results with observed, both April 2009; insets showing the bend in detail.

Measured values have some gaps due to malfunctioning of the automatic sampler.

The combined SWAT and HEC-RAS model supplies flow and sediment time series to the AdH model. Validation of the $\mathrm{AdH}$ model is carried out by comparing simulated with mapped d90 of the upper substrate (Fig. 6) within the modelled reach section. Non-mobile substrates (large wood debris, stones and water plants) have been mapped in the field and are superimposed on the substrate maps. Over the course of the year, most sand fractions have been eroded and transported out of the study reach. In most areas, the model can depict this situation well. In the north-western bend, the model overestimates the d90, which is most likely due to too high flow velocities in the center of the channel (cross section h, Fig. 4). Further upstream (north) lower simulated $\mathrm{d} 90$ values are present at the left bank while this is vice-versa on the recorded substrate map. The narrow, long streak of sand that formed can not be reproduced by the model. The southern, steep curve is simulated well, while further downstream in the straight section, the model AdH overestimates $\mathrm{d} 90$ at the banks. At that location, the AdH model also already overestimated flow velocities at the banks (cross sections d and e, Fig. 4).

The strength of the model cascade is not only the distinction between different sediment pathways on the temporal scale, but also the spatial distribution of sediment loss and change.

Fig. 7 shows the spatial distribution of field, drain and channel sediment origin, simulated with SWAT and HEC-RAS models from April 2008 to April 2009. The spatial distribution of tile drains, evaluated by Fohrer et al. (2007), are shown as hatched areas in Fig. 7. At these locations tile drain sediment is generated. The transported sediment enters the stream at de- fined locations where the tile drain pipes join the river network. Field erosion input into the stream occurs at more erratic locations depending on the overland flow paths. These detailed spatial input patterns are lumped over each SWAT subbasin. The shaded area in the eastern part of the catchment feeds into Lake Winderatt that acts as a sediment trap. Erosion and sedimentation modelled with the HEC-RAS model is shown on the map through lines with alternating thickness within the main stream channel (white), and for a better overview in a separate longitudinal channel change profile. According to field investigations, the spatial channel erosion is plausible. For example, the highest modelled erosive location coincides with a spot where farmers had to move their fences due to the channel bank retreat.

Fig. 8 displays the spatial distribution and temporal change of d90 over the course of the observation year modelled with AdH. The stream bed is relatively stable during most months of the year, for which results are omitted. Major erosive events occur in the winter months November, December and January which coincides with the highest discharge events (Fig. 5).

\section{DISCUSSION AND CONCLUSION}

The first objective of this study was the realistic depiction of water fluxes as a solid basis for erosion and sediment transport simulations. The hydrological model SWAT, applied on the catchment scale, is fitted well to the ten year simulation period. The hydraulic models HEC-RAS and AdH both show good agreement of modelled to measured water depths and flow velocities along the modelled stream channel sections. The HEC-RAS simulation has weaknesses in the depiction of high- 




Fig. 7. Spatially distributed erosion from fields and drains modelled with SWAT and channel change modelled with HEC-RAS including a longitudinal channel change profile, average values over the April 2008-April 2009 time period.

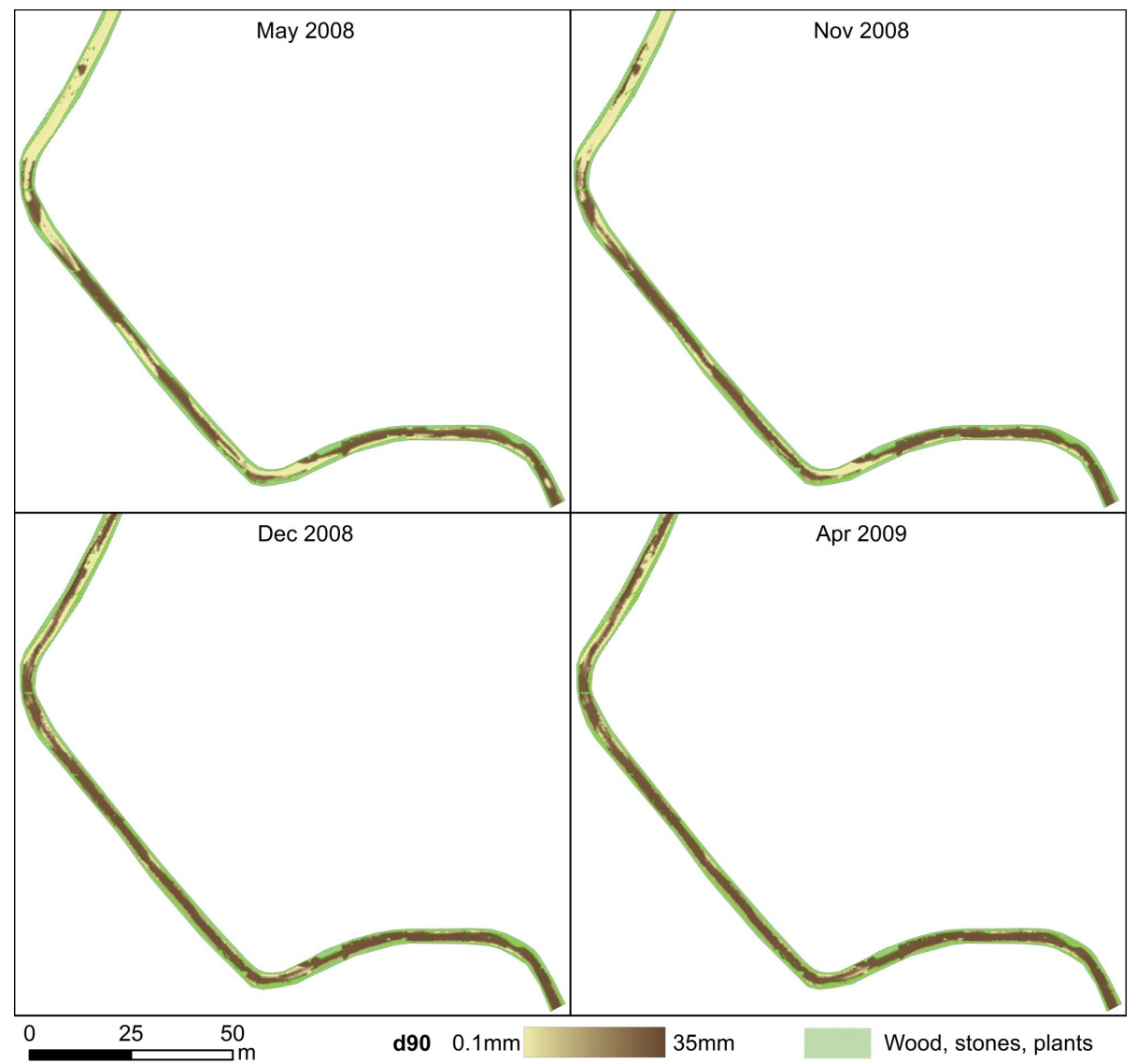

Fig. 8. Spatial distribution and temporal change of d 90 over the course of the observation year modelled with AdH, omitted months have a stable river bed where changes would be only marginally visible.

est flows. This is potentially caused by difficult measurements of hydraulic parameters during those events, which thus contain higher uncertainties. The steep slope of the banks combined with difficulties in referencing the location of the measurements 
within a few centimetres accuracy cause less accurate simulations with $\mathrm{AdH}$. This is especially visible for the return flow cross sections, where in addition, more detailed bathymetry data should have been available upstream and downstream of the cross section. In summary, the quality of the depiction of water fluxes, according to statistical measures researched by Moriasi et al. (2007), is sufficient for simulating erosion and sediment transport processes.

The second objective was the simulation of the three main sediment entry pathways, field-, tile drain-, and channel sediment input in lowlands. The combined SWAT and HEC-RAS sediment simulation has successfully been adapted to the measured sediment load, yielding plausible results for the sediment entry pathway modelling.

The main objective of this study was the application of a three step modelling cascade that is capable of considering impacts of environmental changes on any scale on water and sediment fluxes on the catchment-, channel-, and reach scale. For achieving good simulation results it is necessary to supply comprehensive input data to the model cascade: information is required about the physical environment, from climate, land use and management, to instream characteristics like channel bathymetry, substrate, vegetation, boulders and wood debris. These data requirements and the presented application show that the model cascade is potentially capable to depict global environmental changes as well as anthropogenic stream alterations.

Further research and improvements are suggested in the following points:

(1) the depiction of tile drain sediment load within this study is dependent on empirical relations and is linearly correlated to tile flow. A physically based model of sediment transport in drain flow is still lacking.

(2) The AdH model, driven with data from the combined SWAT and HEC-RAS simulation, is successfully adapted to observed one-year substrate changes. It would be desirable to generate an even better bathymetric database. Also, the changes are a coarsening of the $\mathrm{d} 90$ in most areas of the $230 \mathrm{~m}$ long stream segment. Additional validation of the model cascade for sedimentation events would thus be useful.

(3) A sensitivity test of the input data which is consecutively passed through the total model cascade is desirable. Schmalz et al. (2012b) have shown sensitivity evaluations of the SWAT and HEC-RAS combination. A more comprehensive sensitivity evaluation can potentially be deduced from the IWRM-NET project IMPACT (Guse and Fohrer, 2011; Kail and Wolter, 2012), which currently works towards that objective.

The main advantages of the presented model cascade which can be derived from this study are the following:

(1) the technological status of the individual models is good and will likely remain as such because they are constantly improved and developed. In addition, data preparation and results visualisation as well as data transfer methodologies can be achieved in the flexible GIS environment.

(2) The detached representation and results visualisation of interdependent processes on variable temporal and spatial resolutions is useful. Nested approaches for instream erosion, as described by Piégay et al. (2005), can be depicted by the shown methodology. Also, the separate output of sediment input from field, drains and the river can be utilised for assessing sediment pathways. Depicting these three pathways is especially beneficial in agriculturally used lowland areas since the temporal distinction on a daily time step and the spatially distributed sediment map of the catchment both enable a more detailed investigation and management of sediment input. For the cor- rect assessment of the impact of potential best management practices and their implementation, this detailed analysis of sediment sources is indispensable.

(3) The complementation of one's model's weakness through the previous or next model in the series is valuable: the SWAT model can be applied on very flexible spatial resolutions in the catchment, but high spatial instream resolutions and hydraulic parameters have to be depicted with a hydraulic model. The HEC-RAS model has proven to cover the stream and multiple hydraulic processes well in case hydrological and sediment time series are supplied at all tributaries. However, results are too coarse for micro-scale substrate assessments which are necessary in habitat related studies. The AdH model made it possible to simulate these processes successfully on seamless surfaces in flexible resolutions. Through the automatic meshand time step refinement, the model is stable and user friendly, but the complex flow and sediment transport calculations demand excessive computer power, especially when, as shown, running long-term sediment transport simulations.

(4) Applying the modelling system in different catchments and environments is possible: As shown, the models could be adapted to hydrologic lowland characteristics such as drainages and landscape depressions as well as specific hydraulic conditions of the small, low gradient stream. Beyond that, parts of the presented methodology have recently successfully been utilised in the Kinzig, a mesoscale catchment in Germany's low mountain range (Schmalz et al., 2012a).

(5) The comprehensive consideration of climate, natural and anthropogenic changes, as well as catchment and stream properties makes the model cascade an ideal tool for habitat assessments. The developed methodology was successfully applied by Jähnig et al. (2012) and Schmalz et al. (2012b).

Acknowledgement. The first author has been funded by the German Federal Environmental Foundation (DBU, research grant 20007/897) and in part by the German Academic Exchange Service (DAAD, research grant D/08/43893). We thank Jonathan R. Shewchuk for supplying the Triangle mesh generator, which is part of ArcADH, as an open source program. We also thank Charlie Berger, Jennifer Tate and Gaurav Savant for their guidance on the application of $\mathrm{AdH}$. We appreciate the comments of two anonymous reviewers that improved the quality of the paper.

\section{REFERENCES}

AD-HOC-AG Boden, 2005. Bodenkundliche Kartieranleitung. 5. verbesserte und erweiterte Auflage, Hannover, E. Schweizerbart'sche Verlagsbuchhandlung.

Allen, P.M., Arnold, J.G., Skipwith, W., 2008. Prediction of channel degradation rates in urbanizing watersheds. Hydrological Sciences Journal, 53(5), 1013-1029.

Andersen, H., 2006. Discharge Data Wastewater Treatment Plants. District Schleswig-Flensburg, Water Authority.

Arnold, J.G., Fohrer, N., 2005. SWAT2000: current capabilities and research opportunities in applied watershed modeling. Hydrological Processes, 19, 563-572.

Arnold, J.G., Srinivasan, R., Muttiah, R.S., Williams, J.R., 1998. Large area hydrologic modeling and assessment part I: model development. Journal of American Water Resources Association, 34(1), 73-89.

Baron, J.S., Poff, N.L., Angermeier, P.L., Dahm, C.N., Gleick, P.H., Hairston, N.G., Jackson, R.B., Johnston, C.A., Richter, B.D., Steinman, A.D., 2002. Meeting ecological and societal 
needs for freshwater. Ecological Applications, 12(5), 12471260 .

Baumer, O.W., 1990. Prediction of soil hydraulic parameters. In: WEPP Data Files for Indiana. SCS National Soil Survey Lab. Lincoln, NE.

Berger, R.C., Tate, J.N., Brown, G.L., Savant, G., 2011. Adaptive Hydraulics - A two-dimensional modeling system, Users Manual, Guidelines for Solving Two-Dimensional Shallow Water Problems, AdH Version 4.01. USACE CHLERDC, Vicksburg.

BGR, 1999. Bundesanstalt für Geowissenschaften und Rohstoffe, Bodenübersichtskarte 1:200 000 CC. 1518 Flensburg, Hannover.

Bieger, K., 2007. Integrierte Analyse der Wasserqualität eines Fließgewässers im ländlich geprägten Raum des Norddeutschen Tieflandes. Diploma Thesis, Department of Hydrology and Water Resources Management and Institute of Geography, CAU Kiel.

Borah, D.K., Bera, M., 2004. Watershed-scale hydrologic and nonpoint-source pollution models: Review of applications. Transactions of the ASAE, 47(3), 789-803.

Brown, G.L., Tate, J.N., Savant, G., 2012. SEDLIB Multiple Grain Sized Mixed Sediment Library: Technical Manual. USACE CHL-ERDC, Vicksburg.

Brunner, G.W., 2011. What's new with HEC-RAS. Hydrologic Engineering Centre, U.S. Army Corps of Engineers. USACE Infrastructure Systems Conference, 13-17 June, Atlanta.

Chapman, A.S., Foster, I.D.L., Lees, J.A., Hodgkinson, R.A., 2005. Sediment delivery from agricultural land to rivers via subsurface drainage. Hydrological Processes 19, 2875-2897.

Chow, V.T., 1959. Open-Channel Hydraulics.

Davis, T.A., 2004. A column pre-ordering strategy for the unsymmetric-pattern multifrontal method. ACM Transactions on Mathematical Software, 30(2), 165-195.

DAV-WBV/LAND SH., 2006. Digitales Anlagenverzeichnis Schleswig-Holstein. Wasser- und Bodenverbände des Landes Schleswig-Holstein und Land Schleswig-Holstein.

Deasy, C., Baxendale, S.A., Heathwaite, A.L., Ridall, G., Hodgkinson, R., Brazier, R.E., 2011. Advancing understanding of runoff and sediment transfers in agricultural catchments through simultaneous observations across scales. Earth Surf. Process. Landforms, 36, 1749-1760.

Dickinson, W.T., Rudra, R.P., Wall, G.J., 1989. Nomographs and software for field and bank erosion. Journal of Soil and Water Conservation, 44(6), 596-600.

DLR, 1995. Landsat TM5-Scene, 25 x 25 m resolution. German Aerospace Centre, Köln.

DWD, 2010. Weather and climate data from the German Weather Service. Offenbach, Station Flensburg 1957-2006 and Station Meierwik, 1993-2009, Offenbach.

Etemad-Shahidi, A., Shahkolahi, A., Liu, W.C., 2010. Modeling of Hydrodynamics and Cohesive Sediment Processes in an Estuarine System: Study Case in Danshui River. Environ Model Assess, 15, 261-271.

Florsheim, J.L., Mount, J.F., Chin, A., 2008. Bank erosion as a desirable attribute of rivers. Bioscience, 58(6), 519-529.

Fohrer, N., Schmalz, B., 2012. The UNESCO ecohydrology demonstration site Kielstau catchment - sustainable water resources management and education in rural areas. Hydrologie und Wasserwirtschaft HW, 56(4), 160-168. (In German.)

Fohrer, N., Schmalz, B., Tavares, F., Golon, J., 2007. Modelling the landscape water balance of mesoscale lowland catchments considering agricultural drainage systems. Hy- drologie und Wasserbewirtschaftung, 51(4), 164-169. (In German.)

Gassman, P.W., Reyes, M.R., Green, C.H., Arnold, J.G., 2007. The soil and water assessment tool: historical development, applications, and future research directions. Soil \& Water Division of ASABE, 50(4), 1211-1250.

Golon, J., 2009. Environmental effects of varied energy crop cultivation scenarios on a lowland catchment in northern Germany - A SWAT approach. Master-Thesis. Department of Hydrology and Water Resources Management, CAU Kiel.

Grudzinski, A., 2007. Beurteilung der Wasserqualität von eutrophen Seen im Norddeutschen Tiefland unter Aspekten der historischen und heutigen Landnutzung im Einzugsgebiet. Master Thesis, Department of Hydrology and Water Resources Management, CAU Kiel.

Guse, B., Fohrer, N., 2011. IMPACT project: catchment modelling as a first step in an integrated model approach to couple abiotic and biotic habitat conditions under consideration of climate change effects. Geophysical Research Abstracts, 13, EGU.

Hauer, C., Unfer, G., Tritthart, M., Habersack, H., 2010. Effects of stream channel morphology, transport processes and effective discharge on salmonid spawning habitats. Earth Surf. Process. Landforms, 36, 672-685.

IFM, 2007. Solar radiation data, 8min time-step. Leibniz Institute of Marine Sciences at the University of Kiel.

Jähnig, S.C., Kümmerlen, M., Kiesel, J., Domisch, S., Cai, Q., Schmalz, B., Fohrer, N., 2012. Modelling of riverine ecosystems by integrating models: conceptual approach, a case study and research agenda. Journal of Biogeography, doi:10.1111/jbi.12009.

Janßen, W., 2006. River Basin Management. Lecture notes master course environmental management. Ecology Centre. And personal correspondence.

Jarritt, N.P., Lawrence, D.S., 2007. Fine sediment delivery and transfer in lowland catchments: modelling suspended sediment concentrations in response to hydrological forcing. Hydrological Processes, 21, 2729-2744.

Kail, J., Wolter, C., 2012. Developing an integrated model to predict abiotic habitat conditions and biota of rivers, application in climate change research and water management. IWRM-NET project, grant no. 02WM1134. http://www.impact.igb-berlin.de (accessed 06/2013).

Karypis, G., Kumar, V., 1998. A parallel algorithm for multilevel graph partitioning and sparse matrix ordering. Journal of Parallel Distributed Computing, 48, 71-85.

Kiesel, J., Fohrer, N., Schmalz, B., White, M.J., 2010. Incorporating landscape depressions and tile drainages of a northern German lowland catchment into a semi-distributed model. Hydrological Processes, 24, 1472-1486.

Kiesel, J., Hering, D., Schmalz, B., Fohrer, N., 2009a. A transdisciplinary approach for modelling macroinvertebrate habitats in lowland streams. IAHS Red Book, 328, 24-33.

Kiesel, J., Schmalz, B., Fohrer, N., 2009b. SEPAL - a simple GIS-based tool to estimate sediment pathways in lowland catchments. Advances in Geosciences, 21, 25-32.

Kiesel, J., Schmalz, B., Savant, G., Fohrer, N., 2012. Across the scales: From catchment hydrology to instream hydraulics. $10^{\text {th }}$ International Conference on Hydroinformatics. Proceedings HIC 2012, Hamburg, Germany.

Kirpich, Z.P., 1940. Time of concentration of small agricultural watersheds. Civil Engineering, 10(6), 362 pp.

Kronvang, B., Laubel, A., Grant, R., 1997. Suspended sediment and particulate phosphorous transport and delivery pathways 
in an arable catchment, Gelbaek Stream, Denmark. Hydrological Processes, 11, 627-642.

Labadi, M., 2009. Development of bed load rating curves for a lowland river. Master-Thesis, Department of Hydrology and Water Resources Management, CAU Kiel.

LANU, 2006. Bodendatenbank des Landesamtes für Natur und Umwelt des Landes Schleswig-Holstein, Bodenschätzungsdaten und 657 Bohrlochprofildaten im Einzugsgebiet der Treene. Contact: Dr. Marek Filipinski.

LKN, 2010. Daily discharge data for gauging station Soltfeld (114261), time period 1986-2009. State office for coastal protection, national park and marine protection, Division 2, Department 21, Schleswig.

LVA, 2008. ATKIS@-DEM2 - $1 \mathrm{~m}$ grid size and DEM $5 \mathrm{~m}$ grid size derived from LiDAR data. Land survey office Schleswig-Holstein, Kiel.

LVA, 1992-2004. DEM $25 \mathrm{~m}$ grid size derived from topographic maps 1 : 5000 and aerial photos. Land survey office Schleswig-Holstein, Kiel.

Maharjan, G.R., Park, Y.S., Kim, N.W., Shin, D.S., Choi, J.W. Hyun, G.W., Jeon, J-H., Ok, Y.S., Lim, K.J., 2013. Evaluation of SWAT sub-daily runoff estimation at small agricultural watershed in Korea. Front. Environ. Sci. Eng., 7(1), 109-119.

Merritt, W.S., Letcher, R.A., Jakeman, A.J., 2003. A review of erosion and sediment transport models. Environmental Modelling and Software, 18, 761-799.

Merwade, V., Cook, A., Coonrod, J., 2008. GIS techniques for creating river terrain models for hydrodynamic modeling and flood inundation mapping. Environmental Modelling and Software, 23, 1300-1311.

MOBIO, 1999. Monitoring of Changes in Biotope and Land Use Inventories in Schleswig-Holstein and Denmark by means of Satellite Image Analysis and GIS. DLR, NERI, LANU, CEO.

Moriasi, D.N., Arnold, J.G., Van Liew, M.W., Bingner, R.L., Harmel, R.D., Veith, T.L., 2007. Model evaluation guidelines for systematic quantification of accuracy in watershed simulations. Transactions of the ASABE, 50(3), 885-900.

Neitsch, S.L., Arnold, J.G., Kiniry, J.R., Williams, J.R., 2009. Soil and Water Assessment Tool, Theoretical Documentation, Version 2009. Grassland, Soil and Water Research Laboratory, Blackland Research Centre, Temple, Texas.

Pasternack, G.B., 2011. 2D Modeling and Ecohydraulic Analysis. University of California at Davis.

Piégay, H., Darby, S.E., Moddelman, E., Surian, N., 2005. A review of techniques available for delimiting the erodible river corridor: A sustainable approach to managing bank erosion. River Res. Applic., 21, 773-789.

Post, D.F., Fimbres, A., Matthias, A.D., Sano, E.E., Accioly, L., Batchily, A.K., Ferreira, L.G., 2000. Predicting Soil Albedo from Soil Color and Spectral Reflectance Data. Soil Science Society of America Journal, 64, 1-8.

Russell, M.A., Walling, D.E., Hodgkinson, R.A., 2001. Suspended sediment sources in two small lowland agricultural catchments in the UK. Journal of Hydrology, 252, 1-24.

Schmalz, B., Fohrer, N., 2010. Ecohydrological research in the German lowland catchment Kielstau. IAHS Publication, 336, 115-120.

Schmalz, B., Kiesel, J., Meurer, J., Song, S., Kühling, I., Fohrer, N., 2012a. Hydrologische und hydraulische Untersuchungen im Kinzig-Einzugsgebiet, im Auftrag von Senckenberg, Forschungsinstitute und Naturmuseen. CAU Kiel, Abteilung Hydrologie und Wasserwirtschaft.
Schmalz, B., Kuemmerlen, M., Strehmel, A., Song, S., Cai, Q., Jähnig, S.C., Fohrer, N., 2012b. Integrierte Modellierung von aquatischen Ökosystemen in China: Ökohydrologie und Hydraulik. Hydrologie und Wasserwirtschaft HW, 56(4), 169-184.

Schuol, J., Abbaspour, K.C., Yang, H., Srinivasan, R., Zehnder, A.J.B., 2008. Modelling blue and green water availability in Africa. Water Resources Research, 44, doi: 10.1029/2007WR006609

Schwertmann, U., Vogl, W., Kainz, M., 1987. Bodenerosion durch Wasser, Vorhersage des Abtrages und Bewertung von Gegenmaßnahmen. Ulmer.

soilAQUA, 2009. Cross sectional measurements in the Kielstau river. Engineering Company soilAQUA, Sterup.

Sonntag, D., Heinze, D., 1982. Sättigungsdampfdruck- und Sättigungsdampfdichtetafeln für Wasser und Eis. VEB Deutscher Verlag für Grundstoffindustrie, Leipzig.

Succow, M., Joosten, H., 2001. Landschaftsökologische Moorkunde. Zweite völlig neu überarbeitete Auflage. E. Schweizerbart'sche Verlagsbuchhandlung, Stuttgart.

SWWRP, 2011. System-Wide Water Resources Program. Water Resources Depot. Hydraulic Engineering Centre River Analysis System (HEC-RAS): http://swwrp.usace.army.mil (accessed 10/2011).

Tavares, F., 2006. Continuous, spatially distributed, stream flow and quality assessment of a lowland catchment in Northern Germany. Diploma Thesis. Department of Hydrology and Water Resources Management, CAU Kiel.

Thiemann, K., 2008. Morphological Assessment of a German Lowland Stream as a Basis for Management Recommendations. Master-Thesis. Department of Hydrology and Water Resources Management, CAU Kiel.

Toffaleti, F.B., 1968. Technical Report No. 5. A Procedure for Computation of Total River Sand Discharge and Detailed Distribution, Bed to Surface. Committee on Channel stabilization, U.S. Army Corps of Engineers.

Uri, N.D., 2000. Agriculture and the environment - the problem of soil erosion. Journal of Sustainable Agriculture, 16(4), $71-94$.

USACE, 2011. HEC-GeoRAS, GIS Tools for Support of HECRAS using ArcGIS. User's Manual, Version 4.3.93. US Army Corps of Engineers, Hydraulic Engineering Centre.

USACE, 2010. Hydraulic Reference Manual, Version 4.1. US Army Corps of Engineers, Hydraulic Engineering Centre.

Veihe, A., Jensen, N.H., Schiotz, I.G., Nielsen, S.L., 2011. Magnitude and processes of bank erosion at a small stream in Denmark. Hydrological Processes, 25, 1597-1613.

Williams, J.R., 1995. The EPIC model. In: Computer models of watershed hydrology. (Singh, V.P., ed.). Chapter 25.

Winchell, M., Srinivasan, R., DiLuzio, M., Arnold, J.G., 2007. ArcSWAT Interface for SWAT2005, User's Guide. Blackland Research Centre, ARS Temple, Texas.

Wong, M., Parker, G., 2006. Reanalysis and correction of bedload relation of Meyer-Peter and Müller using their own database. Journal of Hydraulic Engineering, 132(11), 11591168.

Wright, S., Parker, G., 2004. Flow resistance and suspended load in sand-bed rivers: simplified stratification model. Journal of Hydraulic Engineering, 130(8), 796-805.

Yang, C.T., Wan, S., 1991. Comparisons of selected bedmaterial load formulas. Journal of Hydraulic Engineering, 117(8), 973-989.
Received 11 June 2013 Accepted 30 September 2013 